1

\title{
Timely surgical intervention for ureteric complications ensures adequate graft function in renal transplantation: a 10-year review
}

\section{Short running title:}

Renal transplant ureteric complications

\section{Authors:}

- Sherry Salter, ${ }^{1,2}$ MB ChB, FRACS

- $\quad$ Alice Lee, ${ }^{2}$ MD, BBiomed

- Joseph Jaya, ${ }^{2}$ MBBS , MS

- Nancy Suh, ${ }^{1,3}$ MBBS, FRACS

- $\quad$ Ming Kon Yii, ${ }^{1,4}$ MBBS, FRACS, MPH

- Alan Saunder, ${ }^{1,4}$ MBBS, FRACS

${ }^{1}$ Department of Vascular and Transplantation Surgery, Monash Medical Centre, Clayton, VIC, Australia

${ }^{2}$ Department of General Surgery, Monash Medical Centre, Clayton, VIC, Australia

${ }^{3}$ Department of Nephrology Surgery, The Royal Melbourne Hospital, Melbourne, VIC, Australia

${ }^{4}$ Department of Surgery, Monash University, School of Clinical Sciences at Monash Health, Monash Medical Centre, Clayton, VIC, Australia

\section{Corresponding author:}

Ms Sherry Salter

Consultant Transplant and General Surgeon

Department of Vascular and Transplantation Surgery

Monash Medical Centre, Clayton VIC 3168, Australia

Phone: +61 $450682210 \quad$ Fax: +61 (3) 95946053

Email: sherry.salter@monashhealth.org

This is the author manuscript accepted for publication and has undergone full peer review but has not been through the copyediting, typesetting, pagination and proofreading process, which may lead to differences between this version and the Version of Record. Please cite this article as doi: 10.1111/ans.15914

This article is protected by copyright. All rights reserved. 
The corresponding author is not a recipient of a research scholarship. This paper is not based on a previous communication to a society or meeting.

This article is protected by copyright. All rights reserved. 


\section{Word counts (excluding section titles):}

Abstract - 232 words

Main paper (including references, without disclosure statement) - 2974 words

Table 1 and 2 = 500 words (250 words per table)

Figure $1=250$ words ( 250 words per figure)

Total $=232+2974+500+250$ words $=3956$ words

Table 3 (now entitled Table S1) is included as supporting information and thus is not included in the above word count.

This article is protected by copyright. All rights reserved. 


\section{ABSTRACT}

\section{Background}

Ureteric complications can cause significant morbidity in renal and simultaneous pancreaskidney (SPK) transplantation. This 10-year review identified transplant patients with ureteric complications necessitating surgical intervention in an Australian tertiary centre.

\section{Methods}

The hospital records were scrutinised in detail to identify all patients who underwent renal or SPK transplantation from 1 June 2009 to 31 May 2019 with subsequent surgical management of ureteric complications. A case series of patients with ureteric complications was generated and findings analysed.

\section{Results}

A total of 893 renal and SPK transplants were performed over the 10-year period. Ten of these (1.12\%; 7 renal, 3 SPK) had ureteric complications. All were managed surgically. Five of the 10 had ureteric leaks (0.56\%); 3 had ureteric strictures $(0.34 \%) ; 1$ had ureteric obstruction from extraluminal compression (0.11\%); and 1 had both leak and stricture (0.11\%). All 10 patients underwent ureteric reimplantation. Two patients required more than one operation for their ureteric complication. No graft loss or surgical mortality occurred. All 10 patients currently have functioning kidney transplants and none require maintenance dialysis.

This article is protected by copyright. All rights reserved. 


\section{Conclusion}

We report a low rate (1.12\%) of ureteric complications in our renal and SPK transplants. Our standard practice of definitive correction by ureteric reimplantation is proving successful. The authors confirm that appropriate surgery is a viable and durable option in renal transplant patients with excellent graft outcomes.

\section{Keywords}

Renal transplant

Simultaneous pancreas-kidney transplant

Ureteric complication

Ureteric leak

Ureteric stenosis

This article is protected by copyright. All rights reserved. 


\section{INTRODUCTION}

Renal transplantation is accepted as the best treatment modality for patients with end-stage renal failure. It confers a superior quality of life and prolonged overall survival compared to maintenance dialysis. ${ }^{1}$ However, ureteric complications are a potential major cause of morbidity in renal transplantation and may result in transplant failure. ${ }^{2}$ Early diagnosis and management is therefore important when dealing with these complications.

A number of retrospective consecutive series in the literature have investigated the incidence of ureteric complications in renal transplantation. To our knowledge none since Nicol et al. (1993) $)^{3}$ have been reported from an Australasian transplant centre. Ureteroneocystostomy (UNC) anastomotic stenosis and/or leak have been reported to complicate 3-10\% of all renal transplants, and can be a common technical complication associated with renal transplantation..$^{4-6}$ Actions taken at the time of kidney retrieval, back-table dissection and implantation can all impact on the rate of subsequent ureteric complications. ${ }^{2}$

The aim of this study is to review ureteric complications in renal and SPK transplant patients over a 10-year period and to report outcome data for our practice of early definitive surgical intervention. A secondary aim was to provide a case series of surgically managed ureteric complications for training and education.

\section{METHODS}

This article is protected by copyright. All rights reserved. 
This is a retrospective review of all patients over 18 years of age who underwent a renal or SPK transplant between 1st June 2009 and 31st May 2019 at an Australian tertiary transplant centre, identifying those who had a ureteric complication. Two independent search strategies were employed and compared by two separate authors. Any conflict in patients identified were investigated in detail. Patients were identified by searching the hospital business database using the relevant Medicare Benefits Schedule (MBS) codes for ureteric exploration, reimplantation and pyeloplasty procedures at a separate and later time to the transplant procedure. A concurrent and independent search was conducted by a separate author of the hospital transplant database (which is updated and manually maintained current and accurate by a transplant coordinator) paired with an exhaustive review of the medical records to identify all patients with ureteric complications requiring surgical intervention. Operation reports, biochemistry, pathology, radiology and follow-up information were obtained and analysed. The type of donor (donation after brain death (DBD), donation after cardiac death (DCD), or live) and donor age were also noted.

Our transplant unit consists of both consultant general and vascular surgeons who perform the transplant procedures and subsequent operative interventions. During the transplant procedure, we use a modified Lich-Gregoir technique (Figure 1). Our standard practice is to create the UNC by extravesical anastomosis of the ureter to the bladder with $4 / 0$ polydioxanone (PDS ${ }^{\circledR}$ ) suture over a 7 French ureteric double-J stent. Prior to commencing the anastomosis, the bladder is distended with normal saline. A small full-thickness cystotomy is then made. The ureter is measured and trimmed to length and the posterior wall is spatulated. The heel of the 
ureter is secured to the superior aspect of the cystotomy with double-ended 4/0 PDS ${ }^{\circledR}$ suture. One half of the anastomosis is then secured from heel to apex with the suture in a full-thickness single layer. The 7 French double-J stent is then inserted before completing the other side of the anastomosis and securing both sutures from each side of the anastomosis at the apex. Two seromuscular sutures are placed to bury the anastomosis creating a pseudo-tunnel in order to prevent reflux. The ureteric stent placed at the time of transplant is removed approximately 6 weeks later. The 10 patients who required surgical reintervention had the stent removed as an elective procedure 2-5 months post revision surgery. In the transplant recipient (Patient 6; Table 2) with the paediatric donor kidney a smaller-sized 4.8 French ureteric stent was used.

\section{RESULTS}

A total of 893 consecutive renal and SPK transplants (751 renal transplants and 142 SPK transplants) were performed at our institution during the study period. Details of our cohort are shown in Table 1 . Ten patients (1.12\%; 7 renal and 3 SPK transplants) developed ureteric complications. All required surgical reintervention. A summary is provided in Table 2.

Of these 10 patients, the primary causative pathology was defined as ureteric strictures in 3 cases (0.34\%; 3/893), ureteric leak in 5 (0.56\%; 5/893), ureteric obstruction from extraluminal compression in $1(0.11 \% ; 1 / 893)$ and both ureteric leak and stricture in $1(0.11 \% ; 1 / 893)$. The mean age of the recipient (renal transplant or SPK transplant) was 48.9 years (range 23.3-68.2 years). The mean donor age was 38.2 years (range 6.6-63.6 years). The donor breakdown was 6 BDB donors (3 SPK and 3 renal), 2 DCD donors (2 renal) and 2 live donors (2 renal). 
Six patients underwent ureteric reimplantation with an extravesical ureteric anastomosis to the bladder. One patient with a proximal stenosis required mobilisation of the native ureter and an anastomosis formed between the transplant ureter and the native ureter. Two patients (one with an entirely necrotic ureter and another with a urine leak) required mobilisation of the native ureter and had an anastomosis formed between the transplant renal pelvis and the native ureter. One patient with ureteric obstruction (from the round ligament and epigastric vessels) required a pyeloplasty and anastomosis between the transplant kidney pelvic-ureteric junction (PUJ) and transplant ureter. Five patients had ureteric revisions for ureteric leak (1, 3, 21, 22 and 69 days post transplant respectively). One patient required two ureteric revision procedures, performed at 75 days and 154 days post transplant respectively (Patient 6; Table 2). Another patient (Patient 3; Table 2) had two procedures related to ureteric revision as the initial procedure was abandoned due to cardiac arrest following induction of anaesthesia; the definitive ureteric repair was completed 2 days later. Overall, there was no surgical mortality from any procedures performed.

The mean time for the most recent follow-up was 4.5 years post transplant (range 2.2-9.0 years post transplant) with no further complications noted post ureteric revision. Serum creatinine values were obtained for all patients at 1,3 , and 12 months and at the patient's most recent follow-up (Table S1, supporting information). Four of the ten patients had acceptable creatinine levels within the normal range $(60-110 \mu \mathrm{mol} / \mathrm{L})$. Of the 6 remaining patients, four patients (Patients 3, 6, 8 and 9; Table S1) have improving renal function. Although 2 patients (Patient 
1 and 2; Table S1) have a rising creatinine level (after 6 and 5 years post transplant respectively), all 10 patients currently have functioning kidney transplants and none require maintenance dialysis. All 10 patients had no evidence of acute rejection on post-operative biopsies following their ureteric repair.

\section{DISCUSSION}

Despite adequate surgical technique and use of ureteric stents, ureteric stenosis and leaks do occur after renal transplantation but were rare over the period studied $(1.12 \%$ of renal/SPK transplants). Major urological complications from renal transplant surgery have been reported up to $9.2 \% .^{5,7}$ Complications related to the ureter were most common, including urine leak (up to $2.9 \%$ ) and obstruction secondary to stenosis (up to $4.5 \%$ ). ${ }^{4,5,7}$ The most definitive treatment remains as reoperation for restoration of urine outflow, which prevents further injury to the transplant, ${ }^{8}$ even if endoscopic intervention has already been attempted more than 6 months prior to definitive operation. ${ }^{9}$ One systematic review examined 34 articles on ureteric strictures post renal transplant and found that an open approach ureteric reimplantation yielded an $85.4 \%$ success rate compared with $64.3 \%$ for the endourological approach (dilatation, or dilatation combined with laser, electrocautery, and endoureterotomy). ${ }^{10}$ The results from our study confirm that our routine practice of surgical revision can be performed without mortality and with excellent transplant allograft survival.

There are 3 main causes for ureteric complications in renal transplantation: technical reasons (early), ischaemia (late) and extrinsic compression. Urine leak and ureteric stenosis may be due 
to a technically inadequate anastomosis, ${ }^{11}$ and this was the cause of ureteric leak in two of our patients who required return to theatre day 1 post transplant (Patient 1; Table 2) and day 3 post transplant (Patient 2; Table 2). Ischaemia can result from disruption to the vascular integrity of the distal ureter which can happen during retrieval, back-table dissection and UNC. ${ }^{2}$ Blood supply for a native ureter is obtained from both renal arteries and pelvic collaterals, while the transplanted ureter depends solely on blood supply from branches of the renal artery that traverse the periureteric tissues. These tissues contain important arterial branches which supply the distal ureter. Thus, preservation of the periureteric tissues by careful dissection during the retrieval and back-table preparation is vital in decreasing ureteric complications. ${ }^{6}$ Ischaemia tends to result more in intrinsic stricture formation and subsequently ureteric obstruction at the UNC from stenosis, affecting up to $4.5 \%$ of all renal transplant recipients. ${ }^{5,7}$ Our study had 1 patient (Patient 7; Table 2) who developed an ischaemic ureteric stricture due to unintentional ligation of the inferior polar renal artery. This patient had aberrant anatomy with 3 renal arteries with two renal arteries on the carrel patch and the inferior polar renal artery.

The third group includes extrinsic compression (e.g. haematoma, lymphocoele, abscess). This was found in 2 of our patients (Patient 5; Table 2) where a urine leak with subsequent urinoma had caused extrinsic ureteric compression and another patient developing ureteric obstruction from the round ligament and epigastric vessels (Patient 8; Table 2). The authors would recommend that the decision to ligate the round ligament and inferior epigastric vessels should be done on a selective basis and if either or both are not divided, then one must ensure the ureter is placed posterior to these structures. 
Various specific operative and patient factors have been evaluated as predictors of ureteric obstruction following transplantation. ${ }^{14}$ Live renal transplant allografts with renal artery multiplicity and from donors older than 65 years of age were deemed at increased risk of ureteric complications. ${ }^{15}$ The authors of this study propose that multiple renal arteries may correlate with poor inferior pole perfusion, producing relative ischaemia to the ureter. Furthermore, arterial reconstruction of the donor graft has been associated with an increased incidence of urological complications ( $p=0.004$ in one study). ${ }^{16}$ Two of our 10 patients (Patients 4 and 6; Table 2) required renal artery anastomosis revision to obtain adequate renal perfusion, with one returning immediately to theatre to reposition the kidney and thus reduce kinking of the renal arterial vasculature.

The use of ureteric stents and timing for stent removal is debatable in the literature, and varies between centres. Nicol et al. $(1993)^{3}$ and Pleass et al. (1995) $)^{17}$ found that the routine use of indwelling ureteric stents in renal transplantation was associated with a low incidence of urinary leaks, early postoperative obstruction and subsequent surgery for urological complications. Therefore it is common practice to deploy ureteric stents in renal transplantation throughout Australia. Prolonged ischaemia time and UNC without ureteric stent placement have been correlated with ureteric stenosis. ${ }^{14}$ Studies regarding the effectiveness of routine ureteric stent placement during transplantation to prevent urine leak have otherwise produced varying results. ${ }^{18,19}$ A systematic review found no significant difference between early $(<3$ weeks) and late stent removal (>3 weeks) in terms of urinary tract infection and urinary leak 
$(p=0.16) .{ }^{20}$ Recommendations for timing of stent removal (when used) are thus inconsistent. Our standard procedure includes use of a 7 French ureteric double-J stent. The ureteric stent placed at the time of transplant is approximately 6 weeks after the transplant. The 10 patients who required surgical reintervention had the stent removed at an elective procedure 2-5 months post revision surgery. It is possible that the placement of a ureteric stent has contributed to our low rate $(1.12 \%)$ of ureteric leak and ureteral stenosis after renal transplantation along with meticulous surgical technique. Therefore, we would therefore recommend continued use of ureteric stents in our renal transplantation practice.

While surgical management remains a mainstay for definitive management of ureteric complications post transplantation, ${ }^{10,21}$ interventional radiology has a role in selected cases. It offers a less invasive management option, has good technical success rates (depending on the degree of expertise available at the transplant centre), and can help select the right patients to operate on. ${ }^{22}$ Percutaneous therapy is one safe and effective alternative, ${ }^{23}$ and may be useful as a temporary therapeutic procedure for cases of ureteric stenosis prior to attempted stenting and/or dilatation. In ureteric stenosis, balloon dilatation has been proposed to have a greater chance of success compared to stenting, however repeated intervention is often needed to maintain long-term patency. ${ }^{24}$ Overall, there are various recommendations on operative versus interventional radiology techniques. Some groups have found the latter most effective in early ureteric complications (those found within three months from the initial transplant procedure), ${ }^{23}$ and subsequently these patients may be best managed with upfront surgical treatment for long term graft function. Further studies comparing management choices in 
ureteric complications after renal transplantation are required to fully determine their efficacy in comparison to definitive surgical management.

This retrospective review of transplant patients with ureteric complications has allowed us to present a case series of surgically-managed ureteric complications. We are able to report a low rate $(1.12 \%)$ of ureteric complications in our renal transplant and SPK transplant patients, and our standard procedure to correct the ureteric complication has proved successful. All 10 patients currently have functioning kidney transplants with none requiring maintenance dialysis.

In conclusion, we have demonstrated a low rate of ureteric complications within our cohort with the routine use of double-J stents for 6 weeks post transplant and careful preparation of the graft. The authors propose that timely and definitive surgical reintervention is an acceptable management option despite trend toward minimally invasive endourological and radiological options especially in centres without ready access to these services.

\section{Acknowledgements:}

We would like to acknowledge the contribution by Dr Ratheesraj Ratinam BMedSci (Hons), MBBS, PGrad Dip Surg Anat from Monash Health for his illustrations in Figure 1.

\section{Disclosure statement:}


The authors declared no potential conflicts of interest or financial support with respect to the research, authorship, and publication of this article.

\section{REFERENCES}

1. Laupacis A, Keown P, Pus N, Krueger H, Ferguson B, Wong C, Muirhead N. A study of the quality of life and cost-utility of renal transplantation. Kidney International (1996); 50: $235-42$.

2. Buttigieg J, Agius-Anastasi A, Sharma A, Halawa A. Early urological complications after kidney transplantation: An overview. World J Transplant (2018); 8: 142-9.

3. Nicol DL, Ng KP, Hardie DR, Wall DR, Hardie IR. Routine use of indwelling ureteral stents in renal transplantation. J Urol (1993); 150: 1375-79.

4. Englesbe MJ, Dubay DA, Gillespie BW, Moyer AS, Pelletier SJ, Sung RS, Magee JC, Punch JD, Campbell DAJ, Merion RM. Risk factors for urinary complications after renal transplantation. Am J Transplant (2007); 7: 1536-41.

5. Lempinen M, Stenman L, Kyllönen K, Salmela K. Surgical complications following 1670 consecutive adult renal transplantations: a single center study. Scand J Surg (2015); 104: 254-9.

6. Davari HR, Yarmohammadi H, Malekhosseini SA, Salahi H, Bahador A, Salehipour M. Urological complications in 980 consecutive patients with renal transplantation. Int J Urol (2006); 13: 1271-5.

7. Streeter EH, Little DM, Cranston DW, Morris PJ. The urological complications of renal transplantation: a series of 1535 patients. BJU Int (2002); 90: 627-34.

This article is protected by copyright. All rights reserved. 
8. Berli JU, Montgomery JR, Segev DL, Ratner LE, Maley WR, Cooper M, Melancon JK, Burdick J, Desai NM, Dagher NN, Lonze BE, Nazarian SM, Montgomery RA. Surgical management of early and late ureteral complications after renal transplantation: techniques and outcomes. Clin Transplant (2015); 29: 26-33.

9. Helfand BT, Newman JP, Mongiu AK, Modi P, Meeks JJ, Gonzalez CM. Reconstruction of late-onset transplant ureteral stricture disease. BJU Int (2010); 107: 982-7.

10. Kwong J, Schiefer D, Aboalsamh G, Archambault J, Luke PP, Sener A. Optimal management of distal ureteric strictures following renal transplantation: a systematic review. Transpl Int (2016); 29: 579-88.

11. Kumar A, Verma BS, Srivastava A, Bhandari M, Gupta A, Sharma R. Evaluation of the urological complications of living related renal transplantation at a single center during the last 10 years: impact of the Double-J* stent. J Urol (2000); 164: 657-60.

12. Duty BD, Barry JM. Diagnosis and management of ureteral complications following renal transplantation. Asian J Urol (2015); 2: 202-7.

13. Mah TJ, Mallon DH, Brewster O, Saeb-Parsy K, Butler AJ, Bradley JA, Kosmoliaptsis V. Ureteric complications in recipients of kidneys from donation after circulatory death donors. Clin Transplant (2017); 31.

14. Giessing M. Transplant ureter stricture following renal transplantation: surgical options. Transplant Proc (2011); 43: 383-6.

15. Fuller TF, Deger S, Büchler A, Roigas J, Schönberger B, Schnorr D, Tüllmann M, Loening SA, Giessing M. Ureteral complications in the renal transplant recipient after laparoscopic living donor nephrectomy. Eur Urol (2006); 50: 535-40.

This article is protected by copyright. All rights reserved. 
16. Slagt IK, Ijzermans JN, Visser LJ, Weimar W, Roodnat JI, Terkivatan T. Independent risk factors for urological complications after deceased donor kidney transplantation. PLoS One (2014); 9: e91211.

17. Pleass HC, Clark KR, Rigg KM, Reddy KS, Forsythe JL, Proud G, Taylor RM. Urologic complications after renal transplantation: a prospective randomized trial comparing different techniques of ureteric anastomosis and the use of prophylactic ureteric stents. Transplant Proc (1995); 27: 1091-2.

18. Thompson ER, Hosgood SA, Nicholson ML, Wilson CH. Early versus late ureteric stent removal after kidney transplantation. Cochrane Database Syst Rev (2018); 1: CD011455. 19. Dominguez J, Clase CM, Mahalati K, MacDonald AS, McAlisster VC, Belitsky P. Is routine ureteric stenting needed in kidney transplantation? A randomized trial. Transplantation (2000); 70: 597-601.

20. Visser IJ, van der Staaij JPT, Muthusamy A, Willicombe M, Lafranca JA, Dor FJMF. Timing of Ureteric Stent Removal and Occurrence of Urological Complications after Kidney Transplantation: A Systematic Review and Meta-Analysis. J Clin Med (2019); 8: E689.

21. Faenza A, Nardo B, Catena F, Scolari MP, Buscaroli A, D'Arcangelo GL. Ureteral stenosis after kidney transplantation: interventional radiology or surgery? Transplant Proc (2001); 33: 2045-6.

22. Peregrin J, Filipova H, Matl I, Vitko S, Lacha J. Percutaneous treatment of early and late ureteral stenosis after renal transplantation. Transplant Proc (1997); 29: 140-1.

This article is protected by copyright. All rights reserved. 
23. Fonio P, Appendino E, Calandri M, Faletti R, Righi D, Gandini G. Treatment of urological complications in more than 1,000 kidney transplantations: the role of interventional radiology. Radiol Med (2015); 120: 206-12.

24. Aytekin C, Boyvat F, Harman A, Ozyer U, Colak T, Haberal M. Percutaneous therapy of ureteral obstructions and leak after renal transplantation: long-term results. Cardiovasc Intervent Radiol (2007); 30: 1178-84.

\section{LIST OF SUPPORTING INFORMATION}

Table S1: Serum creatinine levels after transplant. 


\section{FIGURE LEGENDS}

Figure 1. Pictorial representation of our ureteroneocystostomy. The heel of the anastomosis is secured with double ended 4/0 PDS suture (A). One half of the anastomosis is then secured from heel to apex with suture in a full thickness single layer (B). A 7 French double-J stent is then inserted before completing the other side of the anastomosis and securing both sutures from each side of the anastomosis at the apex (C and D). 
Table 1: Transplant details for our tertiary centre between $1^{\text {st }}$ June 2009 and $31^{\text {st }}$ May 2019.

\begin{tabular}{|c|c|c|c|c|c|c|c|c|c|c|c|c|c|}
\hline & & 2019 & 2018 & 2017 & 2016 & 2015 & 2014 & 2013 & 2012 & 2011 & 2010 & 2009 & Total \\
\hline \multirow[t]{2}{*}{ Gender } & Male & 26 & 58 & 47 & 63 & 45 & 48 & 49 & 42 & 48 & 37 & 29 & 492 \\
\hline & Female & 18 & 44 & 42 & 45 & 37 & 38 & 37 & 33 & 54 & 40 & 13 & 401 \\
\hline \multirow[t]{3}{*}{ Transplant } & Kidney & 38 & 83 & 73 & 89 & 66 & 71 & 73 & 66 & 95 & 63 & 34 & 751 \\
\hline & SPK & 6 & 19 & 16 & 19 & 16 & 15 & 13 & 9 & 7 & 14 & 8 & 142 \\
\hline & Total & 44 & 102 & 89 & 108 & 82 & 86 & 86 & 75 & 102 & 77 & 42 & 893 \\
\hline \multirow[t]{4}{*}{ Donor } & Live & 7 & 16 & 18 & 27 & 18 & 38 & 25 & 30 & 32 & 30 & 13 & 254 \\
\hline & DBD & 25 & 61 & 52 & 59 & 49 & 31 & 49 & 38 & 53 & 39 & 28 & 484 \\
\hline & DCD & 12 & 25 & 19 & 22 & 15 & 17 & 12 & 7 & 17 & 8 & 1 & 155 \\
\hline & Total & 44 & 102 & 89 & 108 & 82 & 86 & 86 & 75 & 102 & 77 & 42 & 893 \\
\hline
\end{tabular}

$D B D=$ donation after brain death; $D C D=$ donation after cardiac death; $S P K=$ simultaneous pancreas-kidney [transplant]

This article is protected by copyright. All rights reserved. 
Table 2: Data on transplant patients with ureteric complications

\begin{tabular}{|c|c|c|c|c|c|c|c|}
\hline Patient & $\begin{array}{l}\text { Age at TX } \\
\text { (years) }\end{array}$ & Sex & $\mathrm{TX}$ & Donor & $\begin{array}{l}\text { Donor age } \\
\text { (years) }\end{array}$ & Relevant intra-operative findings during the transplant & $\begin{array}{l}\text { TX LOS } \\
\text { (days) }\end{array}$ \\
\hline 1 & 44.3 & Male & SPK & DBD & 42.1 & Routine transplant & 12 \\
\hline 2 & 59.2 & Female & Kidney & Live & 38.4 & Previous SPK in 1996 and a failed kidney transplant. Synchronous left transplant nephrectomy and live kidney transplant & 9 \\
\hline 3 & 39.9 & Female & Kidney & DBD & 62.2 & Routine transplant & 6 \\
\hline 4 & 68.2 & Male & Kidney & DCD & 8.2 & $\begin{array}{l}\text { Two previous renal transplants with a right transplant nephrectomy. Kidney transplant performed via intraperitoneal approach; renal artery } \\
\text { anastomosis revised due to kinking of the renal artery }\end{array}$ & 9 \\
\hline 5 & 52.4 & Female & Kidney & DCD & 6.6 & Routine transplant - Paediatric donor therefore a smaller size $4.8 \mathrm{Fr}$ stent was used & 10 \\
\hline 6 & 23.3 & Male & Kidney & Live & 57.1 & $\begin{array}{l}\text { Renal artery anastomosis required three revisions - initial anastomosis to the external iliac artery, then to the internal iliac artery, then back to } \\
\text { the external iliac artery. Renal US - poor renal perfusion, so returned to theatre. Operation findings - dusky and flaccid renal transplant due to } \\
\text { kinked renal artery. Good perfusion re-established after repositioning the kidney and with mobilisation of the common iliac artery }\end{array}$ & 7 \\
\hline 7 & 53.7 & Male & SPK & DBD & 29.2 & Inferior polar renal artery ligation noted during the back-table; patient had 3 renal arteries with 2 on a carrel patch and the inferior polar artery & 7 \\
\hline 8 & 55.1 & Female & Kidney & DBD & 63.6 & Routine transplant & 11 \\
\hline 9 & 27.1 & Male & SPK & DBD & 35.8 & Routine transplant & 60 \\
\hline 10 & 66.8 & Male & Kidney & DBD & 38.4 & Routine transplant & 8 \\
\hline Mean & 49.0 & - & - & - & 38.2 & - & 25.3 \\
\hline
\end{tabular}

This article is protected by copyright. All rights reserved. 


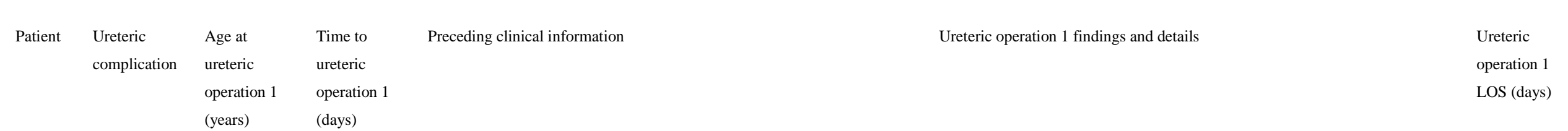

\begin{tabular}{|c|c|c|c|c|}
\hline 1 & Leak & 44.3 & 1 & $\begin{array}{l}\text { - Increasing abdominal pain and distension, low urine output and } \\
>1 \mathrm{~L} \text { serous drain output. DTPA study - suspicious for urine leak }\end{array}$ \\
\hline 2 & Leak & 59.2 & 3 & - $\quad$ DTPA study - suspicious for urine leak \\
\hline 3 & Leak & 40.0 & 21 & $\begin{array}{l}\text { Abdominal wall collection initially thought to be a seroma } \\
\text { drained - 900ml. However fluid creatinine level }=6493 \mu \mathrm{mol} / \mathrm{L} \text {. } \\
\text { Diagnosis of urinoma }\end{array}$ \\
\hline 4 & Leak & 68.2 & 22 & $\begin{array}{l}\text { - Renal tract ultrasound - good renal perfusion, however DTPA } \\
\text { study demonstrated moderate acute tubular necrosis } \\
\text { - Acute lower abdominal pain. CT abdomen - large amount of free } \\
\text { fluid related to the upper pole of the transplant kidney }\end{array}$ \\
\hline 5 & Leak & 52.6 & 69 & $\begin{array}{l}\text { - } \quad \text { Rising serum creatinine up to } 400 \mu \mathrm{mol} / \mathrm{L} \\
\text { - Nephrostogram and CT intravenous pyelogram findings of } \\
\text { ureteric stricture and concurrent urine leak with perinephric } \\
\text { collection }\end{array}$ \\
\hline 6 & $\begin{array}{l}\text { Leak and } \\
\text { stricture }\end{array}$ & 23.5 & 75 & $\begin{array}{l}\text { - Complex post-operative course - transplant ureter stricture } \\
\text { requiring stenting and nephrostogram demonstrated ureteric leak } \\
\text { and urinoma }\end{array}$ \\
\hline 7 & Stricture & 54.0 & 94 & Imaging findings of a ureteric stricture \\
\hline
\end{tabular}

- Ureter sutured to the peritoneum on the dome of the bladder, with urine draining directly into the peritoneal cavity. UNC revised and peritoneum resutured

- Native ureter mobilised to transplant kidney PUJ and formation of end-to-end anastomosis

- Small defect in the distal ureter with urine leak. Operation abandoned as patient became unstable with hypoxia and ventilatory issues with cardiac arrest likely secondary to anaphylaxis

- Emergency laparotomy - urine leak. UNC revised

- Large urinoma cavity adjacent to distal ureter; ureter divided and inspected at the previous UNC but no stricture found. Transplant ureter subsequently reimplanted over a smaller sized stent of $4.8 \mathrm{Fr}$ due to the kidney being from a paediatric donor

- Ureteric leak found approximately 2-3cm from the UNC; suture repair (4/0 PDS) to the ureteric mucosa and muscularis/surrounding tissue and closure of the urinoma cavity (3/0 PDS)

- $\quad$ Revision of UNC performed 
9

28.0

68.6

49.4
167

306

675
- Low urine output after stent removal

- Nephrostogram - PUJ obstruction of the transplant kidney

- Complex post-operative course with urosepsis and recurrent ureteric strictures despite stenting

- Rising creatinine and imaging suggesting hydronephrosis
- Ureteric obstruction due to looping of the round ligament and epigastric vessels; pyeloplasty from transplant ureter to PUJ

- Ureteric revision for high-grade stenosis at the proximal $1 / 3$ of transplant ureter. Native ureter mobilised for an anastomosis onto the transplant kidney PUJ

- Ureteric revision for an ischaemic ureteric stricture

(days)

$\begin{array}{llll} & & - & - \\ 1 & - & - & - \\ 3 & - & 23 & \begin{array}{l}\text { Stabilised with inotropic support and managed in intensive care unit for } 2 \text { days } \\ \text { after first attempt of ureteric repair }\end{array} \\ 4 & 40.0 & - & - \\ 5 & - & - & - \\ 6 & 23.7 & - & \text { Rising creatinine and evidence of hydronephrosis. Ureteric leak detected on } \\ 7 & - & - & - \\ 8 & - & - & - \\ 9 & - & - & - \\ 10 & - & - & -\end{array}$

\section{Necrosis of the entire transplant ureter. Definitive ureteric repair performed by} mobilising native ureter and anastomosis onto the transplant kidney PUJ

Revision of the UNC performed

This article is protected by copyright. All rights reserved. 


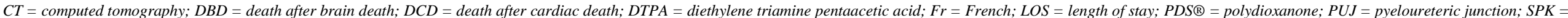
simultaneous pancreas-kidney [transplant]; TX = transplant; UNC = ureteroneocystostomy; US = ultrasound 

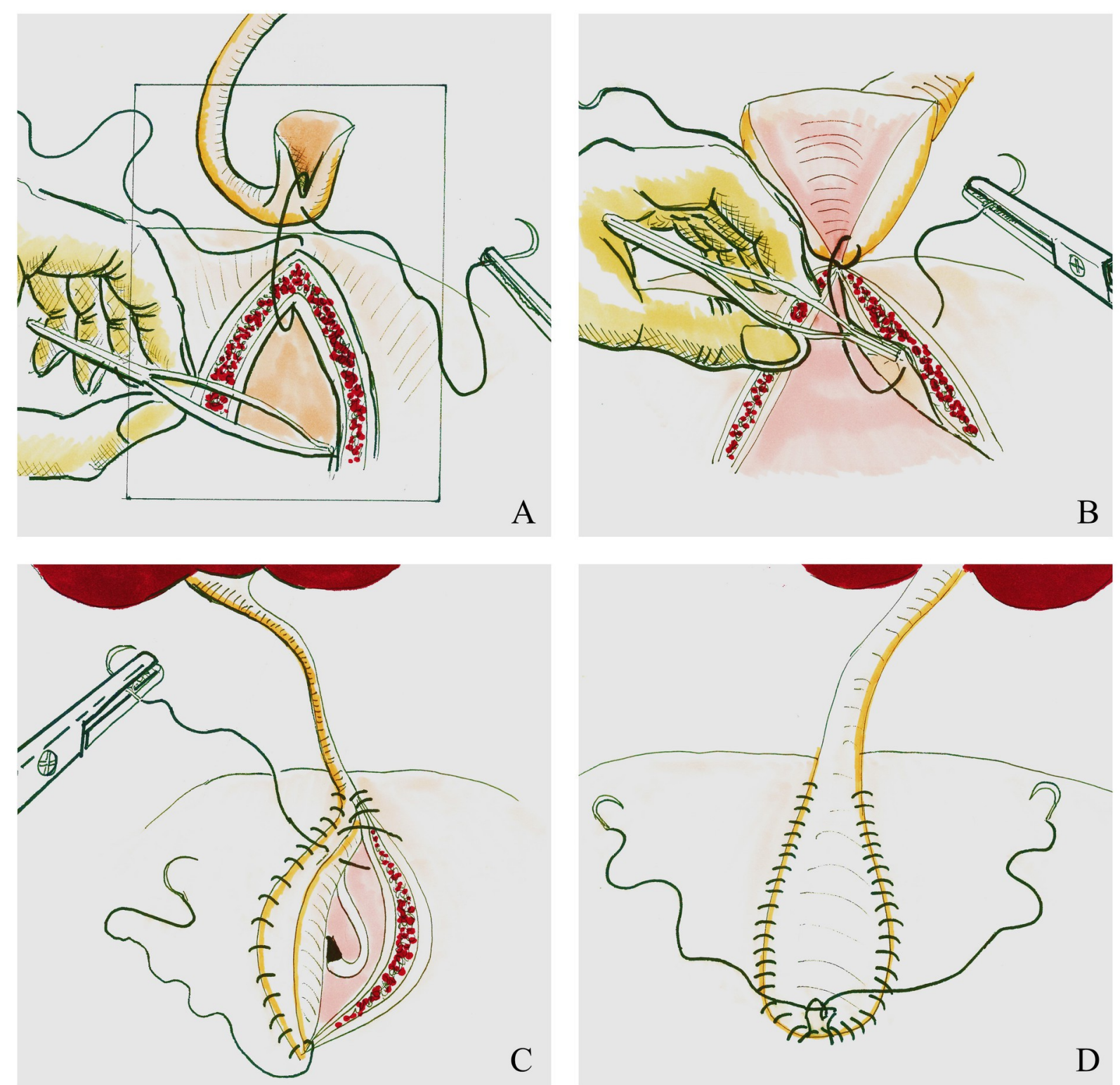

ANS_15914_Figure 1.jpg 


\section{University Library}

\section{- M M N E R VA A gateway to Melbourne's research publications}

Minerva Access is the Institutional Repository of The University of Melbourne

Author/s:

Salter, S;Lee, A;Jaya, J;Suh, N;Yii, MK;Saunder, A

Title:

Timely surgical intervention for ureteric complications ensures adequate graft function in renal transplantation: a 10-year review.

Date:

2020-07

Citation:

Salter, S., Lee, A., Jaya, J., Suh, N., Yii, M. K. \& Saunder, A. (2020). Timely surgical intervention for ureteric complications ensures adequate graft function in renal transplantation: a 10-year review.. ANZ J Surg, 90 (7-8), pp.1340-1346. https:// doi.org/10.1111/ans.15914.

Persistent Link:

http://hdl.handle.net/11343/275727 